\title{
Leadership Development in Ophthalmology: Current Impact and Future Needs
}

\author{
Sean T. Berkowitz, BS ${ }^{1}$ Janice C. Law, MD ${ }^{2}$ Paul Sternberg Jr., MD ${ }^{2}$ Shriji Patel, MD ${ }^{2}$ \\ 1 Vanderbilt University School of Medicine, Nashville, Tennessee \\ 2 Department of Ophthalmology, Vanderbilt University Medical \\ Address for correspondence Shriji Patel, MD, 2311 Pierce Avenue, \\ Nashville, TN 37232 (e-mail: Shriji.patel@vumc.org).
} Center, Nashville, Tennessee

J Acad Ophthalmol 2021;13:e32-e39.

\begin{abstract}
\section{Keywords}

- leadership development program

- ophthalmology

- leadership

Importance There is a lack of peer-reviewed literature on leadership development programs (LDP) in ophthalmology. Research into LDP demographics, outcomes, and methodology is needed.

Objective The aim of the study is to evaluate the extent to which LDPs targeting ophthalmologists meet the needs of emerging leaders.

Design The design type of the study is cross-sectional analysis.

Setting This study involves international setting.

Participants The participants involved were ophthalmologists at any career level.

Methods Routine internet search was used to identify LDPs targeting ophthalmologists. LDPs identified were categorized by the outcome data available into four levels based on prior literature. Participants were assessed using previously validated software for gender (Gender-API, 2020) and race or ethnicity (NamSor, 2020)

Results Nine programs were identified which were classified into LDP generations. The first LDP in ophthalmology was the American Academy of Ophthalmology (AAO) LDP, which served as the nidus for the formation of four multinational LDPs, together forming the Global LDP. These LDPs were similar in size and scope; program size ranging from nine to 30 participants; a length of 1 to 2 years; with similar curricular offerings; with funding primarily derived from cost-sharing with a nominating society. The second generation of ophthalmology LDPs in the United States has targeted female scientists or faculty (Women's LDP by ARVO) and academic ophthalmology leaders (Academic LDP by Association of University Professors of Ophthalmology).

The AAO's LDP appears increasingly diverse with approximately $13 \%$ women at inception, gradually increasing from 40 to $65 \%$ women in the last 5 years $(n=389)$. There has also been a notable increase in ethnic diversity.

Conclusion and Relevance AAO LDP is the preeminent leadership training program for ophthalmologists, and it has influenced the creation of a new generation of LDP offerings. There remains a paucity of LDP evaluation metrics and reported outcomes. Newer iterations are successfully targeting academic leadership and attempting to address known disparities in gender and race or ethnicity. Further expansion of LDPs and related research can ensure equity and diversity in the pipeline.
\end{abstract}

received

October 11, 2020 accepted after revision December 15, 2020
DOI https://doi.org/ $10.1055 / \mathrm{s}-0041-1723001$ ISSN 2475-4757.

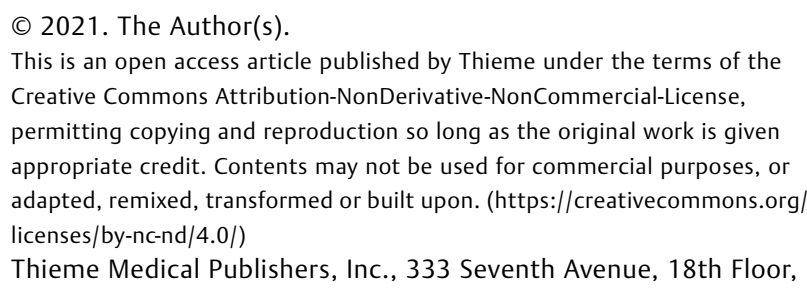


Leadership development programs (LDPs) are important vehicles for the cultivation of leadership talent in the managerial realm. ${ }^{1}$ These programs offer invaluable skills for aspiring leaders, allow opportunities to network with current leaders, and create a talented and prepared pipeline of future leaders. Physician LDPs are increasingly prevalent at academic health centers, ${ }^{2}$ state medical societies, specialty societies, and national medical associations. However, LDPs specifically targeting physicians are difficult to evaluate given marked heterogeneity in structure and protocols across organizations. ${ }^{3}$ Despite the lack of clarity in LDP evaluation in the literature, there are books written on methods for measuring success of LDPs. ${ }^{4}$ LDPs are often evaluated based on some version of Kirkpatrick's four level tool for the evaluation of training programs, ${ }^{5}$ which looks at subjective or objective outcome measures of reaction, learning, behavior, and results. While meta-analyses of physician-targeted LDPs using these categories have demonstrated positive outcomes in all included studies, system-level results and longterm outcomes are studied ${ }^{6}$ infrequently. This corroborates with other systematic reviews of leadership training in medical education $^{7}$ at academic medical centers. ${ }^{8,9}$

Physician leadership can positively impact hospital quality. ${ }^{10}$ There are multifarious leadership roles beyond clinical practice management and departmental chairpersonship including organizational development, medical education, research, editorial scope, politics, advocacy, and quality improvement. Technical skills, emotional intelligence, communication, conflict resolution, negotiation, and advocacy are teachable skills required for successful physician-leaders. ${ }^{11}$ As a result, there is a compelling need to define specific leadership competencies and expand and evaluate emerging LDPs. ${ }^{12}$

Moreover, there are important gender, ${ }^{13}$ race, ethnic, ${ }^{14}$ and other disparities in ophthalmology that may become more concentrated at the leadership level. These disparities need to be addressed from pre-leadership and preophthalmology programming. For example, the Minority Ophthalmology Mentoring (MoM) ${ }^{15}$ program and Rabb-Venable program ${ }^{16}$ were developed to address pipeline issues into ophthalmology training. Recruiting talent is insufficient to address these disparities. Rather, investment in human capital with strategic talent management through formalized programs appears vital.

Given the importance of intentional leadership programs within the field, the American Academy of Ophthalmology (AAO) founded its LDP in 1998. Additional ophthalmologyspecific LDPs have emerged in the last two decades; however, the specific outcomes and degree to which these LDPs contribute to the field of ophthalmology have been minimally described in the literature. As a result, the authors sought to survey the current state of LDPs in the field of ophthalmology and evaluate the evolution of these LDPs and their changing demographics.

\section{Methods}

Identification of LDPs targeting ophthalmologists was found by routine search engine querying for "LDP" and "ophthalmology" (-Table 1). We assessed programs as per their target outcomes following a modified version of Kirkpatrick's fourlevel evaluation ${ }^{5}$ with the following categories: reaction (Level 1), knowledge or learning (subjective; Level 2A), knowledge or learning (objective; Level 2B), behavior/expertise (subjective; Level 3A), behavior/expertise (objective; Level 3B), system results/performance (subjective; Level $4 \mathrm{~A}$ ), and system results/performance (objective; Level 4B), which was sourced directly from prior evaluation of LDPs for physicians. ${ }^{6}$ Categorical levels and representative outcomes are described in - Table 2.

Table 1 Leadership development programs (LDPs) targeting ophthalmologists

\begin{tabular}{|c|c|c|c|c|}
\hline Program & Society/Institution & Size of program & Length & $\begin{array}{l}\text { Year } \\
\text { founded }\end{array}$ \\
\hline AAO leadership development program & $\begin{array}{l}\text { The American Academy of } \\
\text { Ophthalmology (AAO) }\end{array}$ & 18-20 participants & $1 \mathrm{y}$ & 1998 \\
\hline PAAO Curso de Liderazgo & $\begin{array}{l}\text { Pan-American Academy of } \\
\text { Ophthalmology (PAAO) }\end{array}$ & 16-18 participants & $1 \mathrm{y}$ & 2004 \\
\hline $\begin{array}{l}\text { European Society of Ophthalmology } \\
\text { leadership development } \\
\text { program (EuLDP) }\end{array}$ & $\begin{array}{l}\text { European Society of } \\
\text { Ophthalmology (SOE) }\end{array}$ & 30 participants & $2 y$ & 2005 \\
\hline AIOS leadership development program & $\begin{array}{l}\text { All India Ophthalmological } \\
\text { Society (AIOS) }\end{array}$ & 10-22 participants & $1 \mathrm{y}$ & 2008 \\
\hline APAO leadership development program & $\begin{array}{l}\text { Asia-Pacific Academy of } \\
\text { Ophthalmology (APAO) }\end{array}$ & 19 participants & $1 \mathrm{y}$ & 2009 \\
\hline $\begin{array}{l}\text { RANZCO leadership } \\
\text { development program }\end{array}$ & $\begin{array}{l}\text { The Royal Australian and New Zealand } \\
\text { College of Ophthalmologists (RANZCO) }\end{array}$ & Unlisted & $1.5 \mathrm{y}$ & 2014 \\
\hline AOC leadership development program & African Ophthalmology Council (AOC) & 17-20 participants & $2 y$ & 2015 \\
\hline $\begin{array}{l}\text { ARVO Women's leadership } \\
\text { development program }\end{array}$ & $\begin{array}{l}\text { The Association for Research in Vision } \\
\text { and Ophthalmology (ARVO) }\end{array}$ & $\begin{array}{l}9-12 \text { participants } \\
\text { and their mentors }\end{array}$ & $1 \mathrm{y}$ & 2016 \\
\hline $\begin{array}{l}\text { AUPO Academic leadership } \\
\text { development program }\end{array}$ & $\begin{array}{l}\text { The Association of University Professors } \\
\text { of Ophthalmology (AUPO) }\end{array}$ & 10-14 participants & $1 \mathrm{y}$ & 2020 \\
\hline
\end{tabular}


e34 Leadership Development in Ophthalmology Berkowitz et al.

Table 2 Outcome measures for leadership development programs (LDPs) targeting ophthalmologists

\begin{tabular}{|c|c|c|c|c|}
\hline Program & $\begin{array}{l}\text { Capstone project cate- } \\
\text { gories }\end{array}$ & Alumni leadership roles & Awards to LDP & Evaluation categories $^{\mathrm{a}}$ \\
\hline $\begin{array}{l}\text { The American Academy of } \\
\text { Ophthalmology (AAO) lead- } \\
\text { ership development program }\end{array}$ & $\begin{array}{l}\text { Advocacy Projects (26.39\%), } \\
\text { Leadership Development } \\
\text { Projects ( } 2.89 \%), \text { Member- } \\
\text { ship Projects (14.23\%), } \\
\text { Ophthalmic Education } \\
\text { Projects (8.25\%), Ophthal- } \\
\text { mic Training Program } \\
\text { Projects (6.60\%), Organiza- } \\
\text { tional Development Projects } \\
\text { (7.84\%), Practice Manage- } \\
\text { ment Projects (5.57\%), } \\
\text { Public Information/Public } \\
\text { Service Projects (13.81\%), } \\
\text { Quality of Care Projects } \\
\text { (6.60\%), Website Projects } \\
\text { (7.84\%) }\end{array}$ & $\begin{array}{l}\text { " } 277 \text { served as Academy } \\
\text { committee members, } \\
\text { Councilors or Academy } \\
\text { representatives to outside } \\
\text { organizations. } 25 \text { served on } \\
\text { the Academy's Board of } \\
\text { Trustees or Committee of } \\
\text { Secretaries including } 2 \\
\text { Academy Presidents, } 242 \\
\text { have served as president of a } \\
\text { state, subspecialty, or spe- } \\
\text { cialized interest ophthalmol- } \\
\text { ogy society." }\end{array}$ & $\begin{array}{l}\text { "2013 Academy's Special } \\
\text { Recognition Award } 2001 \\
\text { trophy in the American } \\
\text { Society of Association of } \\
\text { Executives' Gold Circle } \\
\text { Awards" }\end{array}$ & $\begin{array}{l}\text { Level 1, Level 2A, Level } \\
\text { 3A, Level 3B, Level 4A, } \\
\text { Level 4B }\end{array}$ \\
\hline $\begin{array}{l}\text { Pan-American Academy of } \\
\text { Ophthalmology (PAAO) } \\
\text { Curso de Liderazgo }\end{array}$ & Capstone projects & $\mathrm{N} / \mathrm{A}$ & $\mathrm{N} / \mathrm{A}$ & Level 4A, Level 4B \\
\hline $\begin{array}{l}\text { European Society of Ophthal- } \\
\text { mology leadership develop- } \\
\text { ment program (EuLDP) }\end{array}$ & Capstone projects & $\mathrm{N} / \mathrm{A}$ & $\mathrm{N} / \mathrm{A}$ & Level 4A, Level 4B \\
\hline $\begin{array}{l}\text { All India Ophthalmological } \\
\text { Society (AIOS) leadership } \\
\text { development program }\end{array}$ & Capstone projects & $\mathrm{N} / \mathrm{A}$ & $\mathrm{N} / \mathrm{A}$ & Level 4A \\
\hline $\begin{array}{l}\text { Asia-Pacific Academy of } \\
\text { Ophthalmology (APAO) } \\
\text { leadership development } \\
\text { program }\end{array}$ & $\begin{array}{l}\text { "Patient care enhancement, } \\
\text { Training and education, } \\
\text { Research and development, } \\
\text { Community work, } \\
\text { Leadership development, } \\
\text { Advocacy" }\end{array}$ & N/A & $\mathrm{N} / \mathrm{A}$ & Level 4A \\
\hline $\begin{array}{l}\text { The Royal Australian and New } \\
\text { Zealand College of Ophthal- } \\
\text { mologists (RANZCO) leader- } \\
\text { ship development program } \\
\text { (LDP) }\end{array}$ & Self-directed project & $\mathrm{N} / \mathrm{A}$ & $\mathrm{N} / \mathrm{A}$ & Level $4 \mathrm{~A}$ \\
\hline $\begin{array}{l}\text { African Ophthalmology } \\
\text { Council (AOC) leadership } \\
\text { development program (LDP) }\end{array}$ & $\begin{array}{l}\text { Projects to benefit } \\
\text { participants' } \\
\text { nominating society }\end{array}$ & $\mathrm{N} / \mathrm{A}$ & $\mathrm{N} / \mathrm{A}$ & Level 4A \\
\hline $\begin{array}{l}\text { The Association for Research } \\
\text { in Vision and Ophthalmology } \\
\text { (ARVO) Women's leadership } \\
\text { development program }\end{array}$ & N/A & $\begin{array}{l}\text { " } 62 \% \text { are currently serving on } \\
\text { an ARVO committee, } 73 \% \text { of } \\
\text { the } 2018-2019 \text { class plans to } \\
\text { pursue a leadership role at } \\
\text { their institution within the } \\
\text { next } 2 \text { y." }\end{array}$ & $\mathrm{N} / \mathrm{A}$ & $\begin{array}{l}\text { Level 1, Level 2A, Level } \\
\text { 3A, Level 3B }\end{array}$ \\
\hline $\begin{array}{l}\text { The Association of University } \\
\text { Professors of Ophthalmology } \\
\text { (AUPO) Academic leadership } \\
\text { development program }\end{array}$ & $\mathrm{N} / \mathrm{A}$ & N/A & $\mathrm{N} / \mathrm{A}$ & $\mathrm{N} / \mathrm{A}$ \\
\hline
\end{tabular}

${ }^{\mathrm{a}}$ Evaluation categories:

Reaction (Level 1).

Knowledge or learning (subjective; Level 2A).

Knowledge or learning (objective; Level 2B).

Behavior/expertise (subjective; Level 3A).

Behavior/expertise (objective; Level 3B).

System results/performance (subjective; Level $4 A$ ).

System results/performance (objective; Level 4B).

Additionally, looking specifically at the AAO LDP, participant demographic changes over time were assessed using previously validated software for gender (Gender-API, 2020) and race or ethnicity (NamSor, 2020).

\section{Systematic Review of Existing Literature}

For context on current analyses of LDPs, a systematic review of publications related to leadership development and ophthal- mology was performed through a modified PRISMA protocol with qualitative analysis ${ }^{17}$ using the electronic databases of PubMed-Legacy, Web of Science, and ERIC (Education Resources Information Center). The search was limited to English publications. Inclusion criteria were initially intended to capture any discussion of LDPs in ophthalmology. Studies exploring leadership across specialties, with specific stratification for ophthalmologists, were included. Exclusion criteria 
included (1) individually written interviews, personal reflections, or lectureships; (2) articles that were published in languages other than English; (3) reference to leadership personnel without discussion of the concept of leadership; (4) articles with no specific reference to ophthalmology. As no protected health information was required to conduct this study, IRB approval was not required.

The initial query focused on LDPs in ophthalmology (Appendix A), which yielded no results in any database. The query was expanded to include the more inclusive phrases of "leadership" AND "ophthalmology" (Appendix B). Institutional Review Board approval was not required for this literature search study.

\section{Results}

LDPs are offered by: $\mathrm{AAO}^{18}$; Asia-Pacific Academy of Ophthalmology (APAO) ${ }^{19}$; The Association for Research in Vision and Ophthalmology (ARVO) ${ }^{20}$; The African Ophthalmology Council (AOC) $)^{21,22}$; The Royal Australian and New Zealand College of Ophthalmologists (RANZCO) ${ }^{23}$; European Society of Ophthalmology $(\mathrm{SOE})^{24}$; All India Ophthalmological Society (AIOS) ${ }^{25}$; Association of University Professors of Ophthalmology (AUPO) ${ }^{26}$; and Pan-American Association of Ophthalmology (PAAO).

The earliest LDP identified was the AAO LDP founded in 1998. Since then, four additional multinational LDPs and two national LDPs have emerged, predominantly with large national or international scope. When reported, program size ranged from 9 to 30 participants. Programs typically spanned 1 to 2 years, and were composed of meetings, forums, networking events, and/or capstone projects. LDPs were primarily funded by cost-sharing mechanisms with a nominating society or the individual participant, with support from industry partners.

Statements from organizational webpages as well as several AAO LDP capstone projects suggest these large multinational LDPs are in fact part of a larger "Global LDP" network ( - Fig. 1). For example, the following multinational and national LDPs were founded either directly from AAO or based on the AAO LDP: AIOS LDP was founded by S. Natarajan, MD (AAO LDP VIII, Class of 2006) $)^{25}$; the APAO LDP was founded by Philip Lam, MD and Catherine Green, MBChB FRANZCO MMedSc in 2009²7; the PAAO LDP was founded by Zelia Correa, MD (AAO LDP V, Class of 2003) ${ }^{28}$; Stefan Seregard, MD cultivated the EuropeanSOE LDP (LDP VI, Class of 2004) after the 2004 AAO-SOE joint meeting; the RANZCO LDP was founded in collaboration with the AAO and APAO ${ }^{29,30}$; the AOC LDP is based on the AAO LDP 29 with leadership from Michael Brennan, MD and Sidney Gicheru, MD for Anglophone, Francophone, and Lusophone Africa. $^{22}$ The Global LDP network of multinational organizations was defined as the first generation of ophthalmologyspecific LDPs, whereas the national LDPs and societal LDPs comprise the second generation.

In addition to these international programs, two programs in the United States were identified, which targeted specific demographics of female scientists or faculty (ARVO Women's LDP) and academic ophthalmology leaders (AUPO Academic LDP). These two programs comprise the second generation of targeted ophthalmology-specific LDPs within the United States (-Fig. 2).

Importantly, the gaps in gender and academia have been addressed by both the ARVO Women's LDP and the newly emerging AUPO Academic LDP. Additionally, AAO LDP capstone projects have focused on diversity, including exploring barriers to a successful match for minorities and surveys to

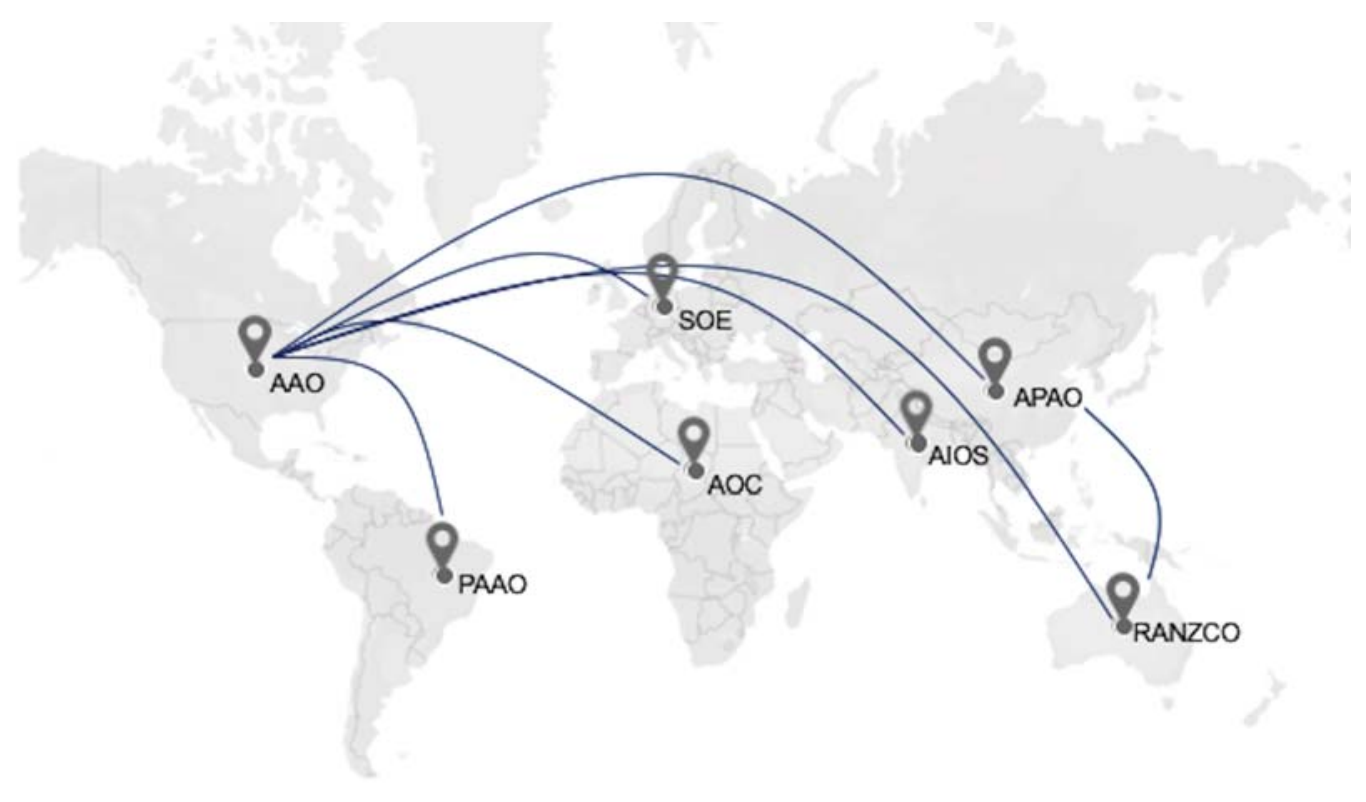

Fig. 1 Elaboration of the Global LDP from the AAO LDP. AAO, American Academy of Ophthalmology; LDP, leadership development program. 


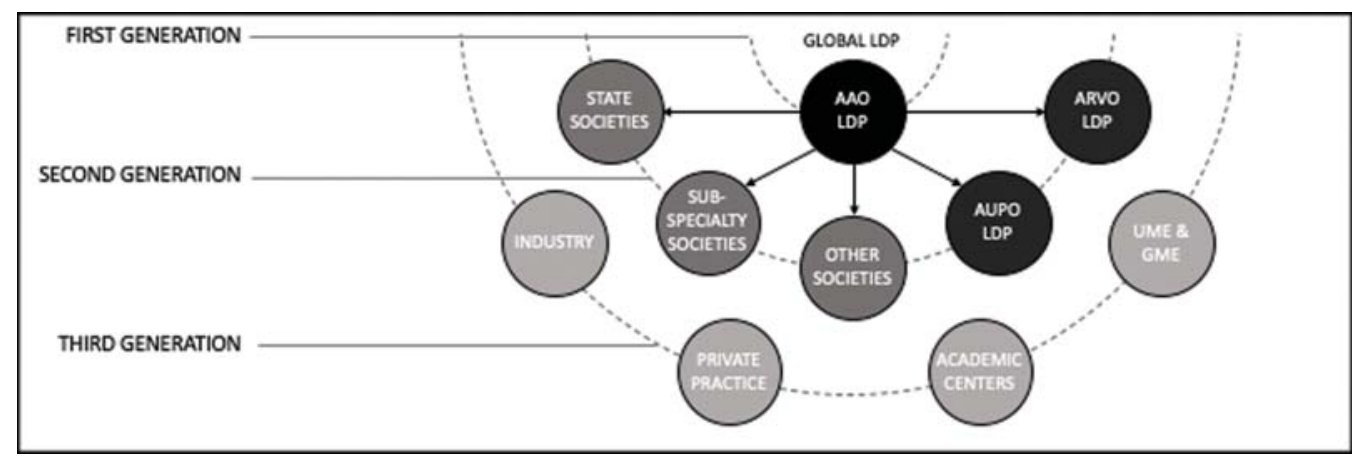

Fig. 2 Schematic of LDPs within the United States. LDP, leadership development program.

characterize interest and increase underrepresented minorities in ophthalmology. These efforts have led to encouraging trends when examining the demographics of AAO LDP participants. There has been a significant increase in the proportion of female LDP participants, which began with roughly $13 \%$ women, and has increased to 40 to $65 \%$ women from 2015 to
2020 ( $n=389)$.There has also been an increasingly diverse membership since inception of the program with representation from all around the world (-Fig. 3 ).

All LDPs alluded to discussion of self-improvement, learning, and behavior changes in their mission and goals; however, specific outcome measures were rarely delineated. The AAO

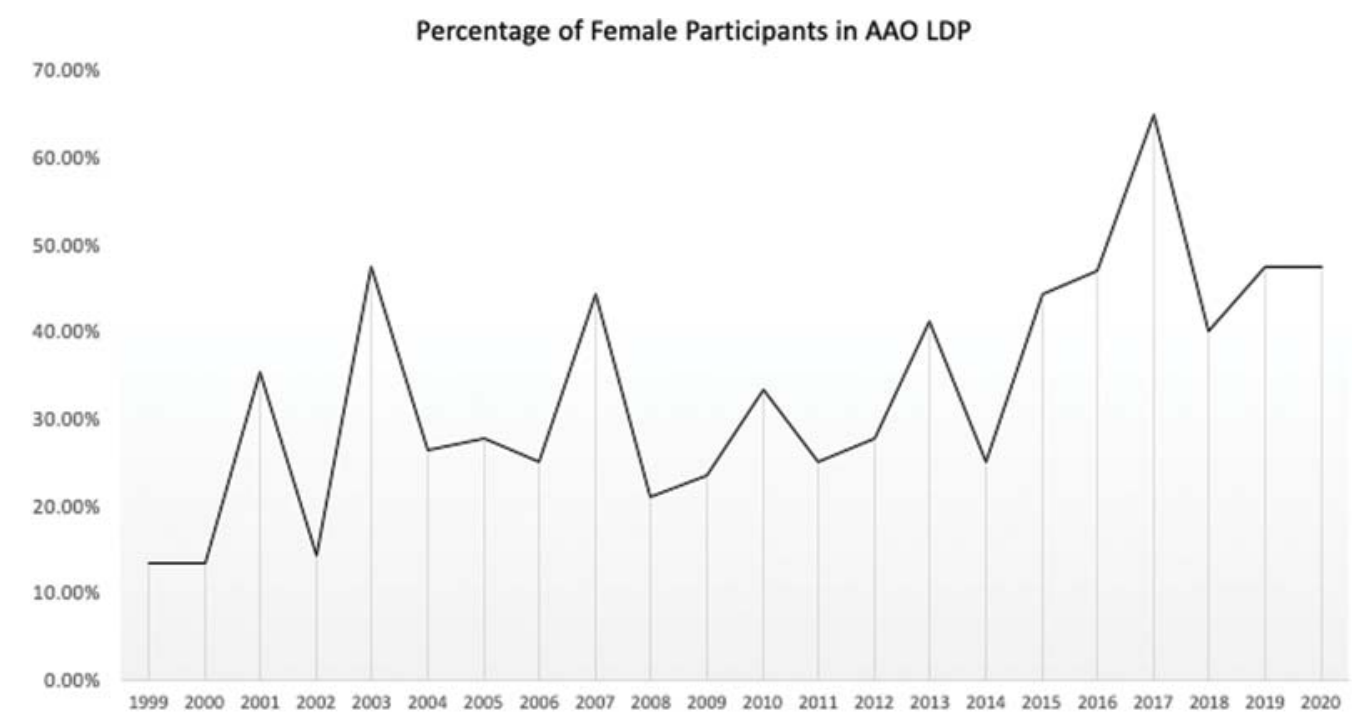

Inferred Ethnic Breakdown of AAO LDP Participants

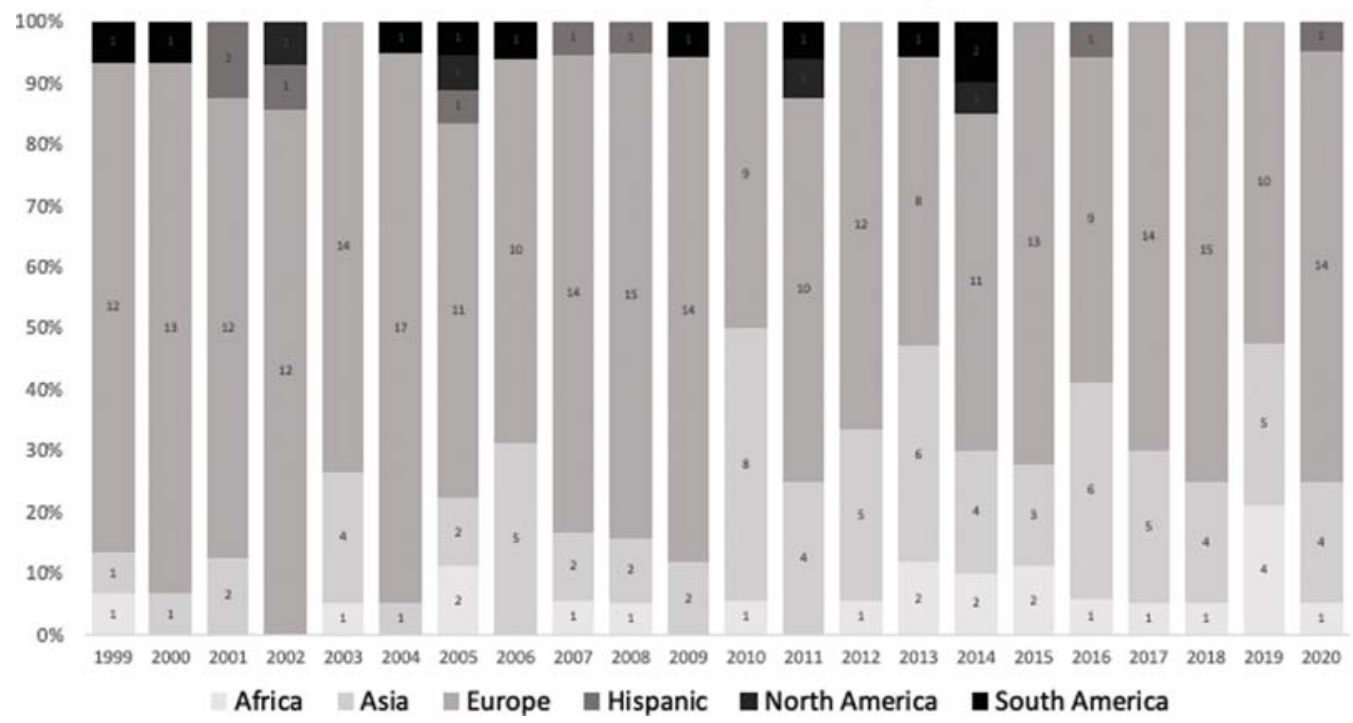

Fig. 3 Demographic distribution of AAO LDP participants over time. AAO, American Academy of Ophthalmology; LDP, leadership development program. 
LDP provided the most comprehensive evaluation category information with subjective evidence from select participants as well as capstone abstracts with organization-level outcomes. The AAO LDP information included all four levels of evaluation; however, objective information regarding learning, which would be acquired from testing of participants, was not present. The ARVO Women's LDP highlighted key outcomes for participants, and provided subjective information on personal growth, but no organization-level outcomes were included. In contrast, the LDPs from the APAO, SOE, AIOS, PAAO, and AOC primarily included a reference to capstone projects without any indication of personal development outcomes. Importantly, project abstracts are available for the AAO LDP, EuLDP, and PAAO programs. These abstracts can be considered Level $4 \mathrm{~B}$ outcomes (objective organizationallevel metrics).

\section{Supplemental Literature Review}

Twenty publications were consistent with inclusion and exclusion criteria. In terms of primary categorical leadership content, academic leadership (journal editorial, academic, or departmental, research funding) was discussed in 55\% of articles, with the remaining literature focused on global or international leadership (10\%), professional society leadership (5\%), post-graduate or surgical leadership training (10\%), and private practice, industry, MBA-ophthalmologist, or general health care leadership (20\%). Most publications addressed gaps in leadership in ophthalmology, with discussion of gender disparity, which was the primary focus of $60 \%$ of articles. With the exception of one study using a curricular intervention, ${ }^{31} 95 \%$ of studies were either cross sectional, review or descriptive report, or observational and retrospective in design. Outcome measures, when available, included gender proportion as well as demographic, professional, and academic profile statistics of specific leadership categories. Publications that were included in the final qualitative analysis are described in Supplementary Table S1. ${ }^{31-50}$

\section{Discussion}

Ophthalmology-specific LDPs are similar to current LDPs at academic health centers ${ }^{2}$ in size, structure, and lack of robust performance metric reporting. The first generation, Global LDP, represented a critical expansion of the AAO's leadership development training internationally. As evidenced by the leadership ophthalmology literature, as well as needs-based capstone projects, cultivation of leadership in specific demographics is needed. Attempts at addressing these gaps are being made by both the ARVO Women's LDP and the newly emerging AUPO Academic LDP, creating more opportunities for women and underrepresented minorities in these programs.

Given the national and international scope of the LDPs identified, we sought to characterize the availability of leadership programs within ophthalmology subspecialty and state societies. While several societies offered honors or awards for leadership, there were no specific LDPs identified, from a nonmember routine internet search, for subspecialty or state ophthalmology societies. Instead these societies utilize the
AAO LDP to train and cultivate leaders for their organizations. With estimates of 17,000 ophthalmologists registered for centers for medicare and medicaid services (CMS), ${ }^{51}$ the AAO LDP program can serve $0.12 \%$ of ophthalmologists in the United States, annually. Adding the ARVO and AUPO LDP offerings would increase this offering to $0.27 \%$. Although leadership training is intended to have far reaching impact beyond the individuals trained, there is a clear dearth of LDPs catered specifically to ophthalmologists. Fortunately, the AAO LDP develops a tremendous leadership capacity for ophthalmology, and AAO LDP graduates have and can continue to create second and third generation programs.

Codifying LDP outcomes will undeniably facilitate the expansion and optimization of second and third generation programs, and provide quantifiable return-on-investment information for organizations that may be hesitant to invest in less empirically validated strategic talent management programs. Empiric evidence for system-level improvement should track clinical, financial, and other organization-specific goals to evaluate the efficacy of LDPs.

There is evidence for significant gender disparities in ophthalmology leadership positions, which is well represented in the literature. For example, department chairs remain predominantly held by men, ${ }^{40,46}$ which may be due to gender disparities in National Institutes of Health funding in ophthalmology, ${ }^{41}$ or a historical lack of women in leadership positions at ophthalmic publications ${ }^{42}$ that remains an important topic of discussion in 2020. ${ }^{32,33,52}$ In fact, there has been a compelling call for gender diversity in ophthalmology leadership due to the disparity between the number of practicing women ophthalmologists and the proportion of women in leadership roles. ${ }^{52}$ This trend is improving but is representative of the gender disparities in national medical societies across specialties. ${ }^{35}$ Despite apparent gender parity in residency, academic leadership is disproportionally male, regardless of chairperson and residency program director gender. ${ }^{44}$ The increasing presence of women in LDPs demonstrated here is an encouraging initial step in creating gender equality in academic leadership. Further targeted LDPs such as the Women's LDP from ARVO can help foster retention of gender diversity in academia through dedicated mentorship.

Similarly, minority groups underrepresented in medicine comprise $30.7 \%$ of the U.S. population, but the proportions of practicing ophthalmologists, ophthalmology faculty, and ophthalmology residents are only $6,5.7$, and $7.7 \%$, respectively. ${ }^{14}$ Therefore, the issue of equity will require early and active intervention. Landmark efforts from the AAO and AUPO, with sponsorship from major ophthalmology societies, to create the MOM program ${ }^{15}$ as well as the National Medical Association's Rabb-Venable ${ }^{16}$ represent an important step in targeted mentoring. These programs may contribute to the third-generation efforts for undergraduate and graduate medical education. Expansion of these efforts must focus ongapsin the pipeline with subsequentand continuous leadership training for later-career ophthalmologists.

U.S. academic ophthalmology department chairs are reportedly $90 \%$ male and predominantly fellowship-trained in Cornea, Vitreoretinal Surgery, and Glaucoma. ${ }^{37}$ The "triple threat" of roles as a clinician, researcher, and educator remains 
relevant, and previous leadership roles are described as invaluable for department ophthalmology chairpersons. ${ }^{40}$ However, the duties of the academic chairperson are dynamic, reflecting an ever-changing health care landscape; therefore, LDPs are vital to provide the newer generation of leaders with necessary skill development. Navigating the political and hierarchical complexity of these organizations may require significant mentorship for aspiring ophthalmologist-leaders. There is a promising opportunity to augment the reach and influence of current leaders through formalized mentorship and expansion of LDPs. Meta-analyses of LDPs at academic health centers suggest most programs are targeted toward early-career physicians, with no programs targeting physicians in top-level leadership roles, ${ }^{6}$ though the AAMC and other organizations provide mid- and early-career leadership training. ${ }^{53,54}$ Leadership development capacity will need to be personalized both to specific demographics and level of career development. Because executive-level ophthalmology mentors are inherently in short supply, top-down LDP and mentorship networks will need to be designed to optimize access and impact.

\section{Conclusion}

There is a paucity of outcome measures for LDPs catered specifically to ophthalmologists, which parallels the lack of peer-reviewed literature describing leadership and ophthalmology. The first generation Global LDP in ophthalmology was spearheaded by the AAO and followed by targeted offerings from ARVO and AUPO. These new programs help address important gaps in ophthalmology leadership described in the literature such as disparities in gender, race, and ethnicity, with a predominant focus on academic ophthalmology leadership roles. Further expansion of formalized leadership training programs is needed to serve a growing population of ophthalmologists facing an exceedingly complex health care landscape. As these programs emerge, detailed research on outcomes from existing LDPs can ensure equity and diversity and allow for successful replication and growth for second and third generation LDP offerings.

\section{Financial Disclosures}

S.T.B. and J.C.L. had no financial disclosure to make. P.S. received financial support from Bridgebio (C) and S.P. from Alcon. P.S., Jr serves as co-director of the AUPO Academic Leadership Development Program.

\section{Financial Support}

Supported in part by an unrestricted departmental award from Research to Prevent Blindness, Inc.

Conflict of Interest

None declared.

\section{Acknowledgment}

The authors thank Rachel Walden, MLIS, Eskind Biomedical Library for his assistance.

\section{References}

1 Collins DB, Holton EF III. The effectiveness of managerial leadership development programs: a meta-analysis of studies from 1982 to 2001. Hum Resour Dev Q 2004;15(02):217-248

2 Moore Simas TA, Cain JM, Milner RJ, et al. A systematic review of development programs designed to address leadership in academic health center faculty. J Contin Educ Health Prof 2019;39(01):42-48

3 McAlearney AS. Leadership development in healthcare: a qualitative study. Journal of Organizational Behavior: the International Journal of Industrial. Occupational and Organizational Psychology and Behavior. 2006;27(07):967-982

4 Hannum KM, Martineau JW, Reinelt C. The Handbook of Leadership Development Evaluation. San Francisco, CA, USA: ERIC; 2007

5 Kirkpatrick D, Kirkpatrick J. Evaluating Training Programs: The Four Levels. San Francisco, CA, USA: Berrett-Koehler Publishers; 2006

6 Frich JC, Brewster AL, Cherlin EJ, Bradley EH. Leadership development programs for physicians: a systematic review. J Gen Intern Med 2015;30(05):656-674

7 Steinert Y, Naismith L, Mann K. Faculty development initiatives designed to promote leadership in medical education. A BEME systematic review: BEME Guide No. 19. Med Teach 2012;34(06):483-503

8 Straus SE, Soobiah C, Levinson W. The impact of leadership training programs on physicians in academic medical centers: a systematic review. Acad Med 2013;88(05):710-723

9 Lucas R, Goldman EF, Scott AR, Dandar V. Leadership development programs at academic health centers: results of a national survey. Acad Med 2018;93(02):229-236

10 Tasi MC, Keswani A, Bozic KJ. Does physician leadership affect hospital quality, operational efficiency, and financial performance? Health Care Manage Rev 2019;44(03):256-262

11 Stoller JK. Developing physician-leaders: key competencies and available programs. J Health Adm Educ 2008;25(04):307-328

12 Stoller JK. Developing physician-leaders: a call to action. J Gen Intern Med 2009;24(07):876-878

13 Lopez SA, Svider PF, Misra P, Bhagat N, Langer PD, Eloy JA. Gender differences in promotion and scholarly impact: an analysis of 1460 academic ophthalmologists. J Surg Educ 2014;71(06):851-859

14 Xierali IM, Nivet MA, Wilson MR. Current and future status of diversity in ophthalmologist workforce. JAMA Ophthalmol 2016; 134(09):1016-1023

15 Olivier MMG, Forster S, Carter KD, Cruz OA, Lee PP. Lighting a pathway: the minority ophthalmology mentoring program. Ophthalmology 2020;127(07):848-851

16 Annual Rabb-Venable Excellence in Ophthalmology Research Program. National Medical Association-Ophthalmology Section. Accessed May 21, 2020, at: http://www.rabbvenable.org/

17 Moher D, Liberati A, Tetzlaff J, Altman DG, Group PPRISMA Group. Preferred reporting items for systematic reviews and meta-analyses: the PRISMA statement. PLoS Med 2009;6(07):e1000097

18 Leadership Development Program. American Academy of Ophthalmology. Accessed 2020 at: https://www.aao.org/about/leadership-development/overview

19 Leadership Development Program. Asia-Pacific Academy of Ophthalmology. Accessed 2020 at: https://www.apaophth.org/apao-ldp/

20 Women's Leadership Development Program. The Association for Research in Vision and Ophthalmology. Accessed 2020 at: https://www. arvo.org/education/Womens-Leadership-development-program/

21 Leadership. The African Ophthalmology Council. Accessed 2020 at: http://www.aofsite.org/en/ldp.html

22 History LDP. The African Ophthalmology Council. Accessed at: http://aoc-online.org/ldp/

23 Leadership Development Program. The Royal Australian and New Zealand College of Ophthalmologists. Accessed 2020 at: https:// ranzco.edu/home/ophthalmologists/leadership-developmentprogram-2/

24 EuLDP. European Society of Ophthalmology (SOE). Accessed 2020 at: https://soevision.org/leadership-program/ 
25 Leadership Development Programme. All India Ophthalmological Society. Accessed 2020 at: https://www.aios.org/article-126-ldpgraduates.php

26 AUPO Academic Leadership Development Program Nominations Due November 15. Association of University Professors of Ophthalmology. Accessed 2020 at: https://aupo.org/news/2019-11/ aupo-academic-leadership-development-program-nominationsdue-november-15

27 Anew chapter in the development of the APAO. Healio Ocular Surgery News. Accessed May 21, 2020 at: https://www.healio.com/ophthalmology/cataract-surgery/news/print/ocular-surgery-news-apaoedition/\%7Bc49ae049-de81-411d-93cb-0327358b54f9\%7D/a-newchapter-in-the-development-of-the-apao

28 LDP Project Abstracts. American Academy of Ophthalmology. Accessed 2020 at: https://www.aao.org/about/leadership-development/project-abstracts

29 Academy Notebook AAO. Academy Notebook-AAO. Accessed May 21, 2020 at: https://www.aao.org/Assets/7088b497-d6a646e2-ada7-974667359d15/635566653571830000/august-2013academy-notebook-pdf

30 EYE2EYE. RANZCO. Accessed May 21, 2020 at: https://ranzco.edu/ wp-content/uploads/2018/10/Spring-2017-Eye2Eye.pdf

31 Shah P, Cross V, Sii F. Sailing a safe ship: improving patient safety by enhancing the leadership skills of new consultant specialist surgeons. J Contin Educ Health Prof 2013;33(03):190-200

32 Camacci ML, Lu A, Lehman EB, Scott IU, Bowie E, Pantanelli SM. Association between sex composition and publication productivity of Journal Editorial and Professional Society Board Members in Ophthalmology. JAMA Ophthalmol 2020;138 (05):451-458

33 Bressler NM. JAMA Ophthalmology-The Year in Review, 2019: striving for sex parity in leadership and excellence in publications. JAMA Ophthalmol 2020;138(05):437-438

34 Yashadhana A, Zhang JH, Yasmin S, et al. Action needed to improve equity and diversity in global eye health leadership. Eye (Lond) 2020;34(06):1051-1054

35 Jagsi R, Means O, Lautenberger D, et al. Women's representation among members and leaders of National Medical Specialty Societies. Acad Med 2019;95(07):1043-1049

36 Gheorghe CM, Purcărea VL, Gheorghe IR, Popa-Velea O. Investigating the dimensions of learning organizations questionnaire (DLOQ) in a Romanian private ophthalmology organization. Rom J Ophthalmol 2018;62(04):288-295

37 Dotan G, Qureshi HM, Gaton DD. Chairs of United States Academic Ophthalmology Departments: a descriptive analysis and trends. Am J Ophthalmol 2018;196:26-33

38 Albert DM, Bartley GB. Open search or rotating leadership: thoughts concerning selecting chairs for an Academic Ophthalmology Department. Ophthalmology 2018;125(02):150-152

39 Pathipati AS, Tsai JC. Leadership in ophthalmology: the role of physician-MBAs. Am J Ophthalmol 2018;188:70-73
40 Dotan G, Qureshi HM, Saraf SS, Darnley-Fisch DA. Leadership of United States Academic Departments of Ophthalmology: chairperson characteristics, accomplishments, and personal insights. Am J Ophthalmol 2018;186:69-76

41 Svider PF, D'Aguillo CM, White PE, et al. Gender differences in successful National Institutes of Health funding in ophthalmology. J Surg Educ 2014;71(05):680-688

42 Mansour AM, Shields CL, Maalouf FC, et al. Five-decade profile of women in leadership positions at ophthalmic publications. Arch Ophthalmol 2012;130(11):1441-1446

43 Mahmoud AO, Nkanga D, Onakoya A. Views of West African surgeons on how well their educational and professional backgrounds may have prepared them for health leadership roles. $\mathrm{N}$ Am J Med Sci 2010;2(12):580-585

44 Shah DN, Volpe NJ, Abbuhl SB, Pietrobon R, Shah A. Gender characteristics among academic ophthalmology leadership, faculty, and residents: results from a cross-sectional survey. Ophthalmic Epidemiol 2010;17(01):1-6

45 Kassam F, Damji KF, Kiage D, Carruthers C, Kollmann KH. The Sandwich fellowship: a subspecialty training model for the developing world. Acad Med 2009;84(08):1152-1160

46 Cruz OA, Johnson NB, Thomas SM. Twenty-five years of leadership: a look at trends in tenure and appointments of chairs of ophthalmology. Ophthalmology 2009;116(04): 807-811

47 Kloosterboer A, Yannuzzi NA, Gedde SJ, Sridhar J. Residency Program Directors of United States Ophthalmology Programs: a descriptive analysis. Am J Ophthalmol 2020;209:71-76

48 Reddy AK, Bounds GW, Bakri SJ, et al. Representation of women with industry ties in ophthalmology. JAMA Ophthalmol 2016;134 (06):636-643

49 Amrein K, Langmann A, Fahrleitner-Pammer A, Pieber TR, Zollner-Schwetz I. Women underrepresented on editorial boards of 60 major medical journals. Gend Med 2011;8 (06):378-387

50 Azuara-Blanco A, Reddy A, Wilkinson G, Flin R. Safe eye surgery: non-technical aspects. Eye (Lond) 2011;25(09):1109-1111

51 Lee CS, Morris A, Van Gelder RN, Lee AY. Evaluating access to eye care in the contiguous United States by calculated driving time in the United States Medicare Population. Ophthalmology 2016;123 (12):2456-2461

52 Colby K. Sex diversity in ophthalmology leadership in 2020-a call for action. JAMA Ophthalmol 2020;138(05):458-459

53 Mid-Career Women Faculty Leadership Development Seminar. Association of American Medical Colleges. Accessed at: https:// www.aamc.org/professional-development/leadership-development/midwims

54 Early Career Women Faculty Leadership Development Seminar. Association of American Medical Colleges. Accessed 2020 at: https://www.aamc.org/professional-development/leadershipdevelopment/ewims 